\title{
Understanding the Impact of Strategic Change Management on the Maritime Crude Oil Transportation Industry in Nigeria
}

\begin{abstract}
Maritime transportation plays a strategically crucial role in the diversification of the Nigerian economy due to its trade (exports and imports) facilitation role in enhancing value chain competitiveness. Thus, this paper investigates the role of strategic change management (SCM) on the Nigerian Maritime Crude Oil Transportation Industry (MCOTI) within the context of Sustainable Development Goals (SDGs). Further, the study finds that both managers and end-users think a 'radical change' rather than a 'gradual change' is needed in the MCOTI in Nigeria. However, both managers and end users gave significantly different reasons for a radical change in the industry. For example, most managers argued that government intervention through deregulation, increased investment in technology and trade facilitation infrastructural development are critical for the survival, restructuring, repositioning, expansion and growth of the industry (in terms of ship registry and number of cabotage vessels in Nigerian coastal waters), while end users focused on product pricing and availability as well as increased opportunities for the vulnerable and economically disadvantaged.
\end{abstract}

Keywords: Sustainable Change Management; Firm Competitiveness; Sustainable Developmental Goals; Inequality; Maritime Crude Oil Transportation; Technology; Infrastructural Development; Trade Facilitation, Nigeria. 


\subsection{Introduction}

'In West Africa, sophisticated piracy both preys upon and arises from the formal economy, specifically the international oil industry. As a result, piracy networks often mirror and draw from both the formal institutions in Nigeria used to regulate and protect oil production, and those engaged in oil production, processing, distribution and transportation.' - (Hastings and Phillips, 2015: 555-576)

Since the beginning of the $21^{\text {st }}$ Century, a diverse range of industries in both developed and developing economies have undergone dramatic transformation, necessitating restructuring of organisations at the functional, business, corporate, and network level towards achieving and sustaining regional and global competitive advantages. With over 80 per cent of world trade merchandise carried by sea and with shipping and ports forming an integral part of all doorto-door transport solutions, the strategic role of sustainable maritime transport and its potential for realising the 2030 Sustainable Development Agenda, and the Paris Agreement under the United Nations Framework Convention on Climate Change, cannot be overemphasised (UNCTAD, 2018). In spite of the many threats to maritime energy trade, which pose huge risk to free movement of ships, transportation of energy resources continues to play a crucial role in ensuring the regular and unhindered supply of energy (Narula, 2019). The strategic and inseparable sectors - crude oil, maritime, $\operatorname{trade}^{1}$ and transportation - remain the backbone of the Nigerian ${ }^{2}$ and West African economy. At present, Nigeria ${ }^{3}$ is one of the top emerging economies in Sub-Saharan Africa, due to its massive reserves of crude oil and

\footnotetext{
${ }^{1}$ More than half of the total value of global seaborne trade involves containerized cargo transported by liner shipping carriers, making maritime transport highly significant for trade, development and economic transformation (UNCTAD, 2018).

2 With abundance oil resources and the largest natural gas reserves on the continent, Nigeria remains a strategic regional player in West Africa, based on its approximately 184 million inhabitants, accounting for 47 per cent of West Africa's population, and having one of the largest populations of youth in world (World Bank, 2019)

${ }^{3}$ The Nigerian Maritime Administration and Safety Agency (NIMASA) Maritime Industry Report 2019 - 2020 places Nigeria as the biggest market in Africa, and generating about 65 - 67 per cent of cargo in West Africa, while 65 per cent of all cargo heading from other regions will most likely end up in the Nigerian market.
} 
other natural resources (Butcher et al., 2012; World Bank, 2017). However, maritime business expansion and economic growth have been discouragingly slow with adverse influence on Nigeria's incapacity to diversify its growth strategy beyond its heavy reliance on the crude oil sector. In spite of its middle-income status, labour-intensive sectors remained weak, thereby resulting in an increase in the rate of unemployment and underemployment, as well as resulting in inequality and incidence of poverty in Nigeria remains high and have been growing rapidly, almost four out of ten people live below the poverty line, steady increase in the number of poor people, thereby indicating significant household vulnerability (Joseph-Raji, Aitalohi, Timmis and Emilika, 2018; World Bank, 2019). By implication, the Gini coefficient for Nigeria is on the higher side compared to other middle-income countries such that inequality grew in $2011-2016$ and the Gini coefficient reached 0.42 . This is consistent with overall poverty rate dynamics in the sense that there is a high share of households clustered around the poverty line and various shocks immediately change the economic status of households (World Bank, 2019).

It is relevant to note that the sluggish expansion of the maritime crude oil transportation industry can be partly explained by illegal oil bunkering, in which the Nigerian State, regional communities in the Niger River Delta, and multinational oil companies are involved, thereby complicating the deteriorating offshore situation in the Gulf of Guinea and collectively eliciting security responses from the Nigerian Government (Vrey, 2012). At the root of these challenges are deep poverty, joblessness, high income inequality, poor governance, weak institutions, poor social and economic conditions, growing number of frustrated youths, natural resources degradation, and climate stressors. In addition, shared prosperity indicators show that growth in consumption between 2011 and 2016 of the bottom 40 percent was negative, while the top 60 saw moderate growth in their mean consumption. (World Bank, 2019). 
Amidst oil price shocks, rampant corruption, burdensome bureaucratic procedures, a weak legal framework and slow progress of regulatory reforms in vital sectors (transport, construction, telecommunication and energy), Nigeria's oil and gas wealth, huge domestic and regional market, rising income in selected cities, and government incentives, facilitate strong trade volumes and diversification efforts at both national and regional levels (Nigeria Trade and Investment Report - Q1-2019 (2019). Years of underinvestment in utilities and transport infrastructure have resulted in a severely constrained transport network across all modes, coupled with a vastly inadequate utilities sector, which is unable to keep pace with growing national and regional demands, thereby undermining Nigeria's attractiveness to investors (Nigeria Logistics Risk Report - Q1-2019). The microeconomic implication of this is the alarming rate of poverty which increased from 35.0 per cent to 38.8 per cent of the total population from 2011-2016. This has also increased the number of economically disadvantaged people within the Nigerian society to grow by 17 million persons ${ }^{4}$ since 2011 . This setback can be related to the rapid increase in the poverty and inequality level of the Nigerian population growth rate (World Bank, 2019).

Further, in order to optimise the comparative advantage that Nigeria's maritime endowments confer regionally and on other parts of the world, the Nigerian Government has continually stimulated inland waterway activities such that major inland water channels are being dredged for ease of navigation through the eastern and northern parts of Nigeria. The aim of government intervention is to foster and contribute towards empowering the different levels of maritime development and poverty reduction in creating decent jobs for the people within the industry. This also contributes to the engagement and empowerment of youth and women in maritime business through the promotion of maritime trade and investment.

Due to these developments, the issue of 'strategic change' at both organisational and

\footnotetext{
${ }^{4}$ Between 2011 and 2016, the total number of people living in poverty increased from 57 million to 74 million.
} 
industrial level continues to be a growing area of interest for academics and government policy makers, in both developed and developing countries, including Nigeria. These developments underpin the rationale for this study, which seeks to investigate the characteristics of strategic change management (SCM) within the maritime crude oil transportation industry (MCOTI) in Nigeria. The overall objective of this study is to investigate the impact of strategic change management in the Nigerian Maritime Crude Oil Transportation Industry (MCOTI), with the overarching aim of providing a better understanding of strategic change management concepts, and how they can be effectively applied within the Nigerian MCOTI.

The remaining part of this paper is divided into four sections. The first section provides a review of relevant literature, thereby underpinning the rationale for the study. The second section provides justification for the choice of research methodology. The third section presents the data analysis collected using questionnaires and semi-structured interviews, followed by a discussion of the quantitative and qualitative results and interpretation of findings. The final section draws conclusions and makes practical recommendations on how strategic change management can be effectively planned, implemented and controlled in the Nigerian MCOTI.

\subsection{A Brief Review of Relevant Literature: Reasons Why Change Management Fails}

The key term in this paper' is 'Strategic Change Management (SCM)', which generally relates to the 'long-term objectives or goals' of an organisation (Kandt, 2002; Chen et al., 2011; Trigeorgis and Reuer, 2016). Indeed, Lindenau and Bohler-Baedaker (2014) suggest that 'SCM' relates to the basic decision-making processes driving the planning, implementation and control activities within an organisation. From a business and management perspective, Oehmichen et al. (2016) suggest that 'strategic change' within an 
industry is a consequence of the ever-changing macro-environment and industry environment. This suggests that 'SCM' provides an opportunity for firms within an industry to change or innovate, in order to achieve and sustain competitive advantage (Barney and Hesterly, 2012; Porter, 1980; Teece, Pisano and Shuen, 1997). In addition, it suggests that firms that understand the structure and level of change needed become more competitive compared to their rivals within the industry in which they operate (Wit and Meyer, 2014; Olayinka and Ogundele, 2015).

The empirical evidence from existing literature and prior studies on business turbulence and development in the global Maritime Crude Oil Transportation Industry (MCOTI) reveals that the industry has gone through a series of reforms, which have contributed significantly to industrial development in many emerging economies, including Nigeria (Igberi and Ogunniyi, 2013; Emenyonu et al., 2016). Prior studies of the Nigerian MCOTI identify significant gaps in the industry's performance and competitiveness in the last decade e.g. the competitiveness of the industry is in decline vis-à-vis the global maritime industry (Ogunniyi and Igberi, 2014; Jaja, 2011; Bello-Olowookere, 2011). This raised fundamental issues relating to the relevance of the theory and practice of SCM in sustaining firm competitiveness within the Nigerian MCOTI. The urgent need to address these issues provides the motivation for this study.

It has been proclaimed that change is a crucial and inevitable scenario within any of today's organisations, individuals, societies and political establishments (Heffron, 1968; Song, 2009). This can be further defined as the engagement of new values, ideology, technology, structure, and attitudes for supporting organisations in taking on a new dimension. The majority of organisations out there still find it hard to effectively integrate change management processes within their working environment and business practices, due to the rejection of change by employees (Fuda, 2013). The literature provides different facts and elements that contribute 
to the failure of a new change management practice within an organisation (Keller and Aiken, 2000; Hayes et al., 2016).

Price and Lawson (2003) consider that the psychological state of an employee could be a determinant factor in the failure or success of organisational change. This was further emphasised with four key-elements. These factors can also be used to depict the behavioural mind-set of the employees with the Nigerian Banking industry by accepting a new change in management practice within the organisation (Nwinyokpugi, 2018). The first element of their argument was said to be the "compelling story", which recommends employees compulsorily accept the change and do not consider their own opinions. The second element is the "role modelling" principle; when a person who is well respected by the people within a particular working environment decides to embrace the change. This decision helps to influence the decisions of other employees in embracing the new change management practice. However, if the "role model" is averse, employees will also show a disregard of the new change management practice. The third element is the "reinforcement system"; if the structure and systems, processes and incentives do not conform with the new change process, the new change management practice may be rendered ineffective. The last element was suggested to be "the skill required for change". This means that when the skills and expertise needed for a particular change practice are not instilled, it might lead to failure of the new change management practice which might be detrimental to the growth and development of the organisation (Ememe, 2017).

Modin (2008) further argued that these four elements can only be achieved in a corruptionfree business environment or society. Considering a developing nation like Nigeria, employers impose their own ideas and understanding of change on their employees, without considering their opinions, contributions, emotional attachment or the impact of this new change on their lives and their jobs (Olarewaju and Folarin, 2012). In other words, this 
signifies that organisations and managers in this part of the world find it difficult to understand the psychological needs of their employees, when it comes to promoting change and reform within the organisation (Bah and Fang, 2011). A good example of this is the 2003 maritime Cabotage Act. This act was incorporated into the Nigerian maritime industry without being effectively communicated to industry stakeholders; neither was consideration given to its short- and long-term benefits, such as the psychological, financial, and industrial impacts on maritime practitioners.

Song (2009) suggests a different context to Price and Lawson's argument. Song used the leadership behaviour principle to justify his argument, mentioning that leadership behaviour within a particular working environment dictates and determines the level of employee commitment, motivation, contribution and participation to any new organisational change. All these can also be related to leadership attributes and traits theories, which drive and enhance a significant input producing effective output, continuous achievement, progressive initiative, and radiative energy (Mantere, 2012; Matthewman, 2013). Bormann and Rowold (2016) mention that participative attributes and traits of leadership give employees a strong emotional sense of belonging, i.e. when their leaders involve them in executing or carrying out a particular task. However, this participative orientation will work effectively in a welldeveloped society, where there is a complete check and balance within the working or business environment (Couturier, 2006). This further implies that participative behaviour might not really achieve a positive outcome within the Nigerian business environment. The fact is that middle-class staff do not have the right to question the authority of the manager (Zuccarro, 2007; Modin, 2008). The Nigerian working environment is assumed to be realistic; a business environment where everybody wants to be the boss or take credit at every stage of a new change management practice being introduced and implemented. In summary, all these setbacks reduce the level of commitment, enthusiasm, and motivation of employees 
to embrace a new organisational change management practice.

The next section depicts the methodology section, which looks at the justification for and impact of the methodology and techniques used for this research paper.

\subsection{Research Methodology and Empirical Analysis}

\subsection{Introduction}

The study used both questionnaire surveys and semi-structured interviews to investigate the impact of strategic change management in the MCOTI in Nigeria. This paper provides justification for using a mixed-method research design in this study. Since the choice of mixed method research provides a more diverse range of information and ensures the reliability of the data collected and results of the study (Creswell, 2013; Saunders et al., 2012) - in this study, a single method approach would not comprehensively answer the research questions (RQ1-RQ4). The questionnaire design for collecting the quantitative data is first discussed below, followed by the semi-structured interview plan for collecting the qualitative data. The questionnaires were administered to 135 top managers and 760 endusers; followed by semi-structured interviews with 13 top managers of firms within the Nigerian Maritime Crude Oil Transportation Industry.

In addition, it explains the process of recruitment and selection of participants for the questionnaire survey and semi-structured interviews, and how the primary data collected were analysed using quantitative and qualitative techniques e.g. IBM SPSS and NVivo software (Firuzjaeyan et al., 2015; Waring and Wainwright, 2008). 


\subsection{Recruitment and Selection of Participants for the Questionnaire Survey and Semi-Structured Interviews}

It is important to note that all the participants for the questionnaire survey and semistructured interviews were Nigerians living in Nigeria. For the questionnaire survey, the recruitment and selection process involved two groups of participants, namely managers and end users.

\section{- Questionnaire respondents:}

For managers /135 managers - the process commenced with initial informal contact being made with potential participants in the Nigerian MCOTI, followed by formal contact. Informal telephone, email, and personal face-to-face contacts were established with the Indigenous Ship Owners Association of Nigeria (ISAN), who operate within the MCOTI through ISAN's personnel department in Lagos, Nigeria. Emails were sent out to a total of 135 ISAN member companies - in some cases, where responses were not forthcoming, telephone calls and personal face-to-face contact were made. 80 out of the 135 ISAN member companies expressed initial interest in participating in the study. This was followed by formal contact through letters and via email, addressed to all 80 companies; 50 out of the 80 companies replied to confirm their willingness to participate in the study - this gives a convenient sample size of 50 ISAN member companies for the study.

For end-users (760 clients/customers) - the recruitment and selection process commenced with identification of one contact person within the 50 firms selected for study. Each contact person was given 20 questionnaires to be given out to end-users, who visited the firm's premises. This means a total of 1,000 questionnaires were administered by convenient sampling of end-users through the contact person in each firm. This recruitment and selection process for the end-users was done within 10 working days, while the administration of the questionnaires to the end-users took 14 working days. During this period, the researcher 
maintained telephone and email contact with all the contact persons to ensure a good response rate was achieved.

- Face-to-face semi-structured interview participants: 13 top managers

For the semi-structured interviews, the recruitment and selection process involved the random selection of top managers from the 50 selected firms. It commenced with initial contact being made by the researcher with potential top managers in the Nigerian MCOTI, followed by formal contact. Informal telephone, email and personal face-to-face contacts were established with the Indigenous Ship Owners Association of Nigeria (ISAN) through ISAN's personnel department. A convenient sampling technique was used to select 5 out of 50 firms, who had earlier agreed to participate in the follow-up semi-structured interviews. This was followed by formal contacts being established with 20 managers within the 5 firms, through email and telephone - out of which 13 volunteered to participate in the semi-structured interviews.

\section{- Hypothesis Test Results}

These hypotheses $(\mathrm{H} 1-\mathrm{H} 3)$ raise fundamental questions about the types of strategic change and how they are being managed - planned, implemented and controlled - in the Nigerian MCOTI, at both organisational and industry levels. Table 3.1 provides a priority scale for the hypotheses test results for hypothesis H1, H2 and H3. In summary, Hypothesis H1 and H3 are rejected and, while the test results for Hypothesis $\mathrm{H} 2$ are inconclusive, hypothesis $\mathrm{H} 2 \mathrm{~b}$ relating to the impact of organic adaptation is rejected.

Table 3.1: Priority Scale for the hypotheses test results for hypothesis H1, H2 and H3

\begin{tabular}{|c|c|c|c|}
\hline $\mathbf{S} / \mathbf{P}$ & Test Results & Hypothesis & Decision \\
\hline & End-users and Factors in the External Environment & H1 & Outcome \\
\hline $1^{\text {st }}$ & $\begin{array}{l}\text { The relationship between government policy and industrial } \\
\text { development }(b=+0.046) \text {, although positive, is not } \\
\text { significant (Sig. } 0.101, p>0.05)\end{array}$ & H1g & $\mathrm{N} / \mathrm{A}$ \\
\hline $2^{\text {nd }}$ & $\begin{array}{l}\text { The relationship between legislation and industrial } \\
\text { development is positive }(b=+0.073) \text { and significant (Sig. }\end{array}$ & H1c & Rejected \\
\hline
\end{tabular}




\begin{tabular}{|c|c|c|c|}
\hline & $0.006, \mathrm{p}<0.05)$ & & \\
\hline $3^{\text {rd }}$ & $\begin{array}{l}\text { The relationship between Global competitiveness and } \\
\text { industrial development is negative }(b=-0.066) \text { and } \\
\text { significant (Sig. 0.025, } \mathrm{p}<0.05)\end{array}$ & $\mathrm{H} 1 \mathrm{i}$ & Accepted \\
\hline $4^{\text {th }}$ & $\begin{array}{l}\text { The relationship between foreign direct investment and } \\
\text { industrial development is positive }(b=+0.428) \text { and } \\
\text { significant (Sig. } 0.000, p<0.05) \text {. }\end{array}$ & H1e & Rejected \\
\hline $5^{\text {th }}$ & $\begin{array}{l}\text { The relationship between Technological innovation and } \\
\text { industrial development is negative }(b=-0.036) \text { and not } \\
\text { significant (Sig. } 0.240, p>0.05)\end{array}$ & $\mathrm{H} 1 \mathrm{~h}$ & $\mathrm{~N} / \mathrm{A}$ \\
\hline $6^{\text {th }}$ & $\begin{array}{l}\text { The relationship between industry investment and industrial } \\
\text { development is positive }(b=+0.091) \text { and significant (Sig. } \\
0.002, \mathrm{p}<0.05)\end{array}$ & $\mathrm{H} 1 \mathrm{~b}$ & Rejected \\
\hline $7^{\text {th }}$ & $\begin{array}{l}\text { The relationship between substitutes and industrial } \\
\text { development is positive }(b=+0.055) \text { and significant (Sig. } \\
0.030, p<0.05) \text {. }\end{array}$ & H1a & Rejected \\
\hline \multirow[t]{2}{*}{$8^{\text {th }}$} & $\begin{array}{l}\text { The relationship between bulk transportation and industrial } \\
\text { development }(\mathrm{b}=+0.036) \text {, although positive, is not } \\
\text { significant with (Sig. } 0.189, \mathrm{p}>0.05)\end{array}$ & H1f & N/A \\
\hline & Managers and Types of Strategic Change in the MCOTI & $\mathrm{H} 2$ & Outcome \\
\hline $1^{\text {st }}$ & $\begin{array}{l}\text { The relationship between response to cabotage act and the } \\
\text { need for gradual change in the MCOTI is positive }(b=+010) \\
\text { and not significant (Sig. } 0.899, p<0.05)\end{array}$ & $\mathrm{H} 2 \mathrm{j}$ & $\mathrm{N} / \mathrm{A}$ \\
\hline $2^{\text {nd }}$ & $\begin{array}{l}\text { The relationship between continuous improvement and the } \\
\text { need for gradual change in the MCOTI is negative }(b=- \\
0.204 \text { ) and not significant (Sig. } 0.278, p<0.05)\end{array}$ & $\mathrm{H} 2 \mathrm{a}$ & N/A \\
\hline $3^{\text {rd }}$ & $\begin{array}{l}\text { The relationship between holistic decision making and the } \\
\text { need for gradual change in the MCOTI is negative }(b=-0.058) \\
\text { and not significant (Sig. } 0.775, p<0.05)\end{array}$ & $\mathrm{H} 2 \mathrm{c}$ & $\mathrm{N} / \mathrm{A}$ \\
\hline $4^{\text {th }}$ & $\begin{array}{l}\text { The relationship between purposeful change and the need for } \\
\text { gradual change in the MCOTI is positive }(b=+200) \text { and not } \\
\text { significant }(\text { Sig. } 0.070, p<0.05)\end{array}$ & $\mathrm{H} 2 \mathrm{~d}$ & N/A \\
\hline $5^{\text {th }}$ & $\begin{array}{l}\text { The relationship between crisis management and the need for } \\
\text { gradual change in the MCOTI is negative }(b=-057) \text { and not } \\
\text { significant (Sig. } 0.557, p<0.05)\end{array}$ & $\mathrm{H} 2 \mathrm{~g}$ & N/A \\
\hline $6^{\text {th }}$ & $\begin{array}{l}\text { The relationship between being proactive and the need for } \\
\text { gradual change in the MCOTI is positive }(b=+010) \text { and not } \\
\text { significant }(\text { Sig. } 0.893, p<0.05)\end{array}$ & $\mathrm{H} 2 \mathrm{f}$ & N/A \\
\hline $7^{\text {th }}$ & $\begin{array}{l}\text { The relationship between maintaining status quo and the need } \\
\text { for gradual change in the MCOTI is positive }(b=+117) \text { and } \\
\text { not significant (Sig. } 0.188, p<0.05)\end{array}$ & $\mathrm{H} 2 \mathrm{e}$ & N/A \\
\hline $8^{\text {th }}$ & $\begin{array}{l}\text { The relationship between level of uncertainty and the need for } \\
\text { gradual change in the MCOTI is negative }(b=-115) \text { and not } \\
\text { significant (Sig. } 0.384, p<0.05)\end{array}$ & $\mathrm{H} 2 \mathrm{~h}$ & N/A \\
\hline $9^{\text {th }}$ & $\begin{array}{l}\text { The relationship between long-term orientation and the need } \\
\text { for gradual change in the MCOTI is negative }(b=-063) \text { and } \\
\text { not significant (Sig. } 0.643, p<0.05)\end{array}$ & $\mathrm{H} 2 \mathrm{i}$ & N/A \\
\hline
\end{tabular}


$\mathbf{1}^{\text {st }} \quad$ The relationship between managers' need for radical change and the type of strategic change in MCOTI, is positive $(b=$

+0.610 ), and is significant (Sig. 0.001, p $<0.05$ )

Source: Author's compilation and calculations

\subsection{Discussion and Interpretation of Findings}

- Hypothesis 1 - Using multiple regression analysis

\section{The multiple regression model:}

The multiple regression model (Model 1) the form of the equation (1):

H1: End-users do not think a radical change is needed in the maritime crude oil transportation industry (MCOTI) in Nigeria.

$I D_{\text {strategic change }}=b_{0}+b_{1}($ substitutes $)+b_{2}($ ind_invetment $)+b_{3}($ tech_innovation $)+b_{4}$ (legislation $)+b_{5}($ bulk_transportation $)+b_{6}($ gov_policy $)+b_{7}($ global_comp $)+b_{8}$ (verti_integration $)+b_{9}($ fdi $)+e^{*}(1)$

Where:

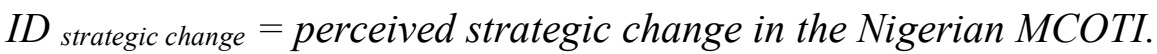

Predictors: substitutes; industry investment, technological innovation, government legislation; bulk transportation; government policy; global competitiveness; vertical integration; foreign direct investment.

b-values: $b_{0} ; b_{1} ; b_{2} ; b_{3} ; b_{4} ; b_{5} ; b_{6} ; b_{7} ; b_{8} ; b_{9} ; e^{*}=$ error term $=0.176$

- The relationship between the substitutes and industrial development is positive $(b=$ +0.055 ) and significant (Sig. 0.030, $p<0.05$ ). This means the null H1 should be rejected. We therefore accept the alternative hypothesis that an increase in the level of substitutes leads to an increase in industrial development.

- The relationship between industry investment and industrial development is positive $(b=+0.091)$ and significant (Sig. 0.002, $p<0.05)$. This means the null H1 should be rejected. We therefore accept the alternative hypothesis that an increase in industry investments leads to an increase in industrial development.

- The relationship between legislation and industrial development is positive $(b=$ +0.073 ) and significant (Sig. 0.006, $p<0.05$ ). This means the null H1 should be rejected. We therefore accept the alternative hypothesis that an increase in legislation leads to an increase in industrial development.

- The relationship between vertical integration and industrial development is positive $(b=+0.234)$ and significant (Sig. 0.000, $p<0.05)$. This means the null H1 should be rejected. We therefore accept the alternative hypothesis that an increase in vertical integration leads to an increase in industrial development.

- $\quad$ The relationship between foreign direct investment and industrial development is positive $(b=+0.428)$ and significant (Sig. 0.000, $p<0.05)$. This means the null H1 
should be rejected. We therefore accept the alternative hypothesis that an increase in foreign direct investment leads to an increase in industrial development.

- However, the relationships between industrial development and bulk transportation $(b=+0.036)$ and government policy $(b=+0.046)$, although both positive, they are insignificant with (Sig. 0.189, $p>0.05$ ) and (Sig. 0.101, $p>0.05$ ) respectively.

In contrast, the results also show a negative and significant relationship between the following independent variables and industrial development:

- Technological innovation has a negative $(b=-0.036)$ and insignificant (Sig. 0.240, $p$ $>0.05)$ relationship with industrial development. This means the null H1 should be accepted, because an increase in technological innovation according to end users has not led to an increase in industrial development.

- Global competitiveness has a negative $(b=-0.066)$ and significant (Sig. 0.025, $p<$ $0.05)$ relationship with industrial development. This means the null H1 should be accepted, because an increase in global competitiveness has not led to an increase in industrial development.

In summary, from the above results, we reject the null hypothesis $\mathrm{H} 1$, and accept the alternative hypothesis that an increase in the threat of substitutes, increase in industry investment, progressive legislation, increase in vertical integration, and increase in foreign direct investment, are drivers for strategic change in MCOTI. However, an increase in technological innovation and global competitiveness support hypothesis H1.

- Hypotheses (H2) - Managers: Simple Linear Regression Analysis H2 (Managers do not think a gradual change is needed in the MCOTI in Nigeria)

In order to operationalise Hypothesis H2 (Managers do not think a gradual change is needed in the MCOTI in Nigeria), this researcher developed the following related sub-hypotheses: H2a: Managers do not think that continuous improvement is needed in the MCOTI in Nigeria; H2b: Managers do not think that organic adaptation is needed in the MCOTI in Nigeria; H2c: Managers do not think that holistic decision-making is needed in the MCOTI 
in Nigeria; H2d: Managers do not think that purposeful change is needed in the MCOTI in

Nigeria; H2e: Managers do not think that maintaining the status quo is needed in the MCOTI in Nigeria; H2f: Managers do not think that being proactive is needed in the MCOTI in Nigeria; H2g: Managers do not think that crisis management is needed in the MCOTI in Nigeria; H2h: Managers do not think that high level uncertainty is needed in the MCOTI in Nigeria; H2i: Managers do not think that long-term orientation is needed in the MCOTI in Nigeria, and $\mathrm{H} 2 \mathrm{j}$ : Managers do not think that the cabotage act is needed in the MCOTI in Nigeria.

The multiple regression models for equation (2):

$I D_{\text {strategic change }}=b_{0}+b_{1}($ gradual_change $)+e^{*}(2)$

Where:

ID strategic change $=$ perceived strategic change in the Nigerian MCOTI.

Predictors: gradual change.

$b$-values: $b_{0} ; b_{1} ; e^{*}=$ error term

\section{Hypothesis (H3) Testing - Standard Multiple Regression Analysis}

H3 (Managers do not think a radical change is needed in the MCOTI in Nigeria);

The multiple regression model for equation (3):

$I D$ strategic change $=b_{0}+b_{1}($ radical_change $)+e^{*}(3)$

Where:

ID strategic change $^{=}$perceived strategic change in the Nigerian MCOTI.

Predictors: radical change.

$b$-values: $b_{0} ; b_{1} ; e^{*}=$ error term

Multiple Regression Analysis of End-user and Managers Survey Data

\section{End users' demographic characteristics}

Table 3.2 presents the percentage of respondents for three demographic characteristics: gender, age and education of end users. For example, of the total 760 end users, 47.4\%, (360 respondents) were male, and 52.6\% (400 respondents) were female. In addition, with regards 
to the age of respondents, 150 respondents (19.7\%) were below 30 years of age, 500 respondents $(65.8 \%)$ fell between the 30-50 age-bracket, and 110 respondents $(14.5 \%)$ were aged 50 and over.

Table 3.2: Questionnaires to End Users $(\mathbf{N}=\mathbf{7 6 0})$

\begin{tabular}{|l|c|c|}
\hline Male & Gender & $47.4 \%$ \\
\hline Female & 460 & $52.6 \%$ \\
\hline Total & $\mathbf{7 6 0}$ & $\mathbf{1 0 0 \%}$ \\
\hline Below 30 years & Age & \\
\hline Between 30-50 & 150 & $19.7 \%$ \\
\hline years & 500 & $65.8 \%$ \\
\hline Above 50 years & 110 & $14.5 \%$ \\
\hline Total & $\mathbf{7 6 0}$ & $\mathbf{1 0 0 \%}$ \\
\hline High School & Education & \\
\hline Associate/Diploma & 60 & 7.9 \\
\hline College Degree & 86 & 11.3 \\
\hline Graduate & 504 & 66.3 \\
\hline $\begin{array}{l}\text { No formal } \\
\text { education }\end{array}$ & 73 & 9.6 \\
\hline Total & 34 & 4.5 \\
\hline
\end{tabular}

With regards to education levels, 7.9\% (60 respondents) had High School Level Certificates, 11.3\% (86 respondents) had associate / diplomas, 66.3\% (504 respondents) had college education degrees, $9.6 \%$ (73 respondents) had graduate degrees, and the remaining $4.5 \%$ (34 respondents) had no formal educational qualifications.

It can be opined that the high your level of education within the Nigerian society can also justify your level of earnings as an employee within an organisation. However, it can also be seen from a different perspective that, a person been well educated might not justify their level of earnings due to nepotism, inequalities, corruption in the society and to mention a few. The next section looks at the demographic characteristics of managers within the industry. 


\section{Managers' demographic characteristics}

Table 3.3 presents the percentage of respondents for six demographic characteristics: gender, age, education, income level, management level and business location for managers and professionals in the MCOTI in Nigeria.

Table 3.3: Questionnaires to Managers $(\mathbf{N}=135)$

\begin{tabular}{|c|c|c|}
\hline \multicolumn{3}{|c|}{ Gender } \\
\hline Males & 119 & $88.1 \%$ \\
\hline Females & 14 & $10.4 \%$ \\
\hline Not Prepared to Disclose & 2 & $1.5 \%$ \\
\hline Total & 135 & $100 \%$ \\
\hline \multicolumn{3}{|c|}{ Age } \\
\hline & & Total \\
\hline Below 30 years & 1 & $1(0.07 \%)$ \\
\hline Between 30-50 years & 64 & $64(47.4 \%)$ \\
\hline Above 50 years & 69 & $69(51.1 \%)$ \\
\hline Not Prepared to Disclose & 1 & $1(0.07 \%)$ \\
\hline Total & 135 & $135(100 \%)$ \\
\hline \multicolumn{3}{|c|}{ Education } \\
\hline & & Total \\
\hline High School Certificate & 1 & $1(0.07 \%)$ \\
\hline Associate/Diploma & 7 & $7(5.2 \%)$ \\
\hline College Degree & 38 & $38(28.1 \%)$ \\
\hline Graduate & 89 & $89(65.9 \%)$ \\
\hline No formal education & 0 & $0(\%)$ \\
\hline Total & 135 & $135(100 \%)$ \\
\hline \multicolumn{3}{|c|}{ Income Level } \\
\hline Below 10 million Naira & 55 & $55(40.7 \%)$ \\
\hline $\begin{array}{c}\text { Between 10-15 million } \\
\text { Naira }\end{array}$ & 36 & $36(26.7 \%)$ \\
\hline $\begin{array}{c}\text { Between 15-20 million } \\
\text { Naira }\end{array}$ & 20 & $20(14.8 \%)$ \\
\hline Above 20 million Naira & 24 & $24(17.8 \%)$ \\
\hline Total & 135 & $135(100 \%)$ \\
\hline \multicolumn{3}{|c|}{ Management Level } \\
\hline Manager & 67 & $67(49.6 \%)$ \\
\hline Director & 21 & $21(15.6 \%)$ \\
\hline Chief Executive & 45 & $45(33.3 \%)$ \\
\hline $\begin{array}{l}\text { Not Prepared to } \\
\text { Disclose }\end{array}$ & 2 & $2(0.15 \%)$ \\
\hline Total & 135 & $135(100 \%)$ \\
\hline \multicolumn{3}{|c|}{ Business Location } \\
\hline South of Nigeria & 9 & $9(6.7 \%)$ \\
\hline $\begin{array}{c}\text { East or Niger Delta of } \\
\text { Nigeria }\end{array}$ & 7 & $7(5.2 \%)$ \\
\hline West of Nigeria & 119 & $119(88.1 \%)$ \\
\hline
\end{tabular}


For example, of the total 135 respondents, $88.1 \%$ (119 respondents) were male, $10.4 \%$ (14 respondents) were female and 2 respondents $(1.5 \%)$ were not willing to disclose their gender for their own personal reasons. In addition, with regards to the age of respondents, 1 respondent $(0.7 \%)$ was below 30 years of age, 64 respondents $(47.4 \%)$ fell in the $30-50$ years of age bracket, and 69 respondents $(51.1 \%)$ were aged 50 years and above. The next section provides the thematic results from the manual and NVivo content analysis from the semistructured interviews.

\subsection{Thematic Results from the Manual and NVivo Content Analysis of the Semi- Structured Interviews Involving Top Managers from the MCOTI Industry in Nigeria}

The semi-structured interviews involved 13 top managers from five top companies in the MCOTI in Nigeria. The interview sessions were conducted over four weeks at different locations within Lagos, Nigeria. All the interviews were tape-recorded and transcribed verbatim, and both manual and electronic files were kept in a secured player for analysis. Each interview transcript was uploaded into NVivo and the responses to questions were appropriately coded using pre-codes e.g. SCM Planning for radical change (Plan-rc), SCM Planning for continuous change (SCM-Plan-cc), Macro-environmental factors at local and global levels: Mef-pol-local; Mef-pol-glob, Industry factors: MCOTI-entrants; MCOTIentrants-terrorism. The data cloud from NVivo, based on the actual words used by participants, is presented in Figure 3.1, which indicates high levels of construct validity, in the sense that most of the actual words used by participants e.g. maritime, Nigeria change management, transportation, government, completion, policies/legislation, implementation, international/foreign, market, NIMASA, and indigenous, match with most of the pre-codes for the content analysis. This figure, however, does not show the relationship between the codes or words used by participants, as such, further content analysis was conducted e.g. 
cluster analysis, which gave the hierarchical relationship between the codes/words used by participants. 
Figure 3.1: Nvivo Data Cloud based on 13 Participants Word Frequency

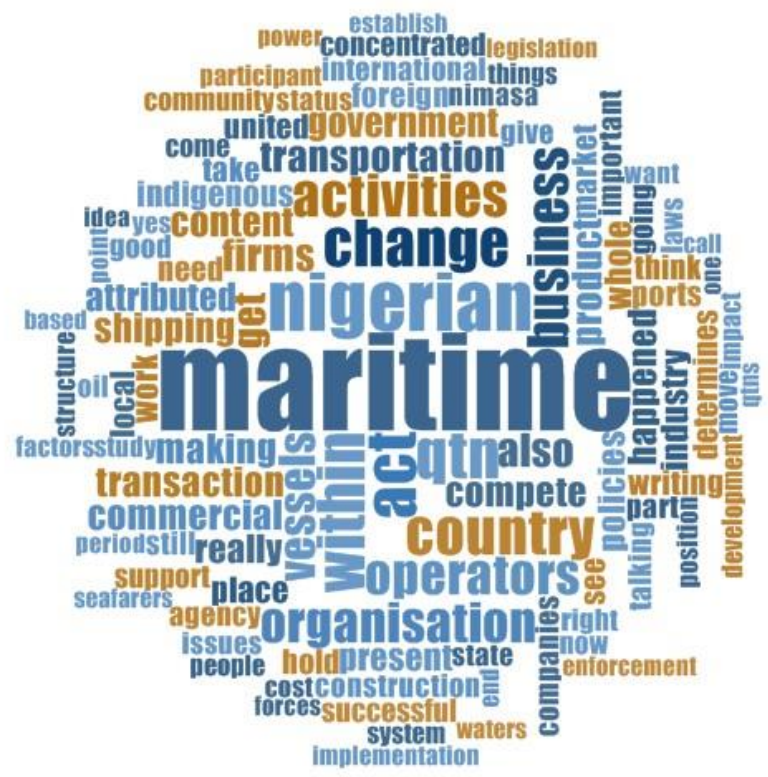

Source: Author's compilation and analysis

The thematic analysis created an opportunity for the researcher to become more familiar with the data. This helped the researcher to make notes of new themes emanating from the interviews and to update the pre-selected codes (Braun and Clarke, 2008). In summary, from Figure 3.1 we can see that the interview participants were more concerned about the changes and policies within the Nigerian maritime transportation industry. NVivo cluster analysis reveals the hierarchical relationships between the codes/nodes or words used by participants.

3.5

The proposed holistic strategic change management framework for sustaining competitiveness in the Nigerian MCOTI

Figure 3.2 shows a holistic framework based on the results and findings from the quantitative and qualitative analyses in this chapter. It is important to note that the main purpose of the exploratory quantitative data is to test existing theories relating to the effectiveness of strategic change management in the Nigerian MCOTI. In contrast, the main purpose of the 
qualitative data is to validate and evaluate the quantitative findings. As such, the framework has two key building blocks as its foundation. The first building block reflects the internal factors influencing the types of strategic change management approaches adopted by the 13 top managers who participated in the semi-structured interview. The second building block reflects the changes in macro-environmental and industry factors identified by both end-users and top managers who participated in the exploratory questionnaire survey. The framework assumes that a holistic business model for achieving strategic fit between firms' internal environment and external environment can be developed through the adoption of either a radical or gradual approach to strategic change management. For this to happen, top managers' attitudes towards key internal factors e.g. long-term orientation, level of uncertainty, proactiveness, and holistic decision-making process, need to be critically evaluated, in the context of the changes in both macro-environmental and industry factors. In this study, the key drivers of strategic change include political and economic factors, and the key inhibitors are both technological innovation and global competitiveness. 
Figure 3.2

The Proposed Holistic Strategic Change Management Framework for Sustaining Competitiveness in the Nigerian MCOTI

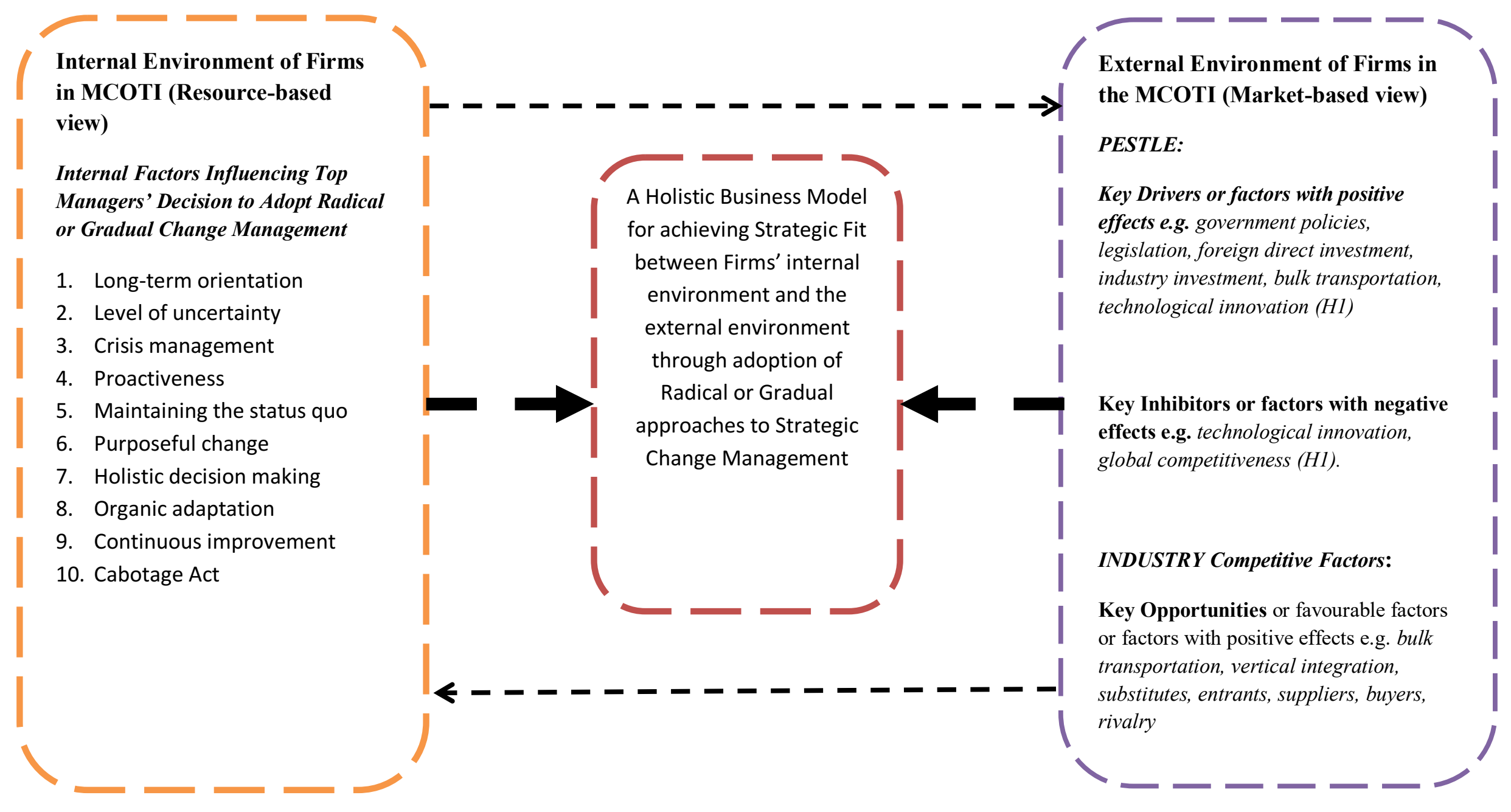


The key implication of the above framework is that the effective implementation of strategic change management by firms within the Nigerian maritime industry would determine the sustainability of the business models for competitive advantage in the MCOTI. It is important to note that the soundness of the framework is because it is grounded in the actual data collected (quantitative and qualitative research) and has a sound theoretical grounding in the strategic change management literature. This underpins the study's contribution to knowledge in the specific areas of radical and gradual change management approaches to revamping the MCOTI in Nigeria, considering the fast-changing nature of global and local macro-environmental and industry demand for maritime crude oil transportation.

In summary, the results from the analyses of the questionnaire survey of 760 end-users and 135 top managers, and the semi-structured interviews of 13 top managers reveal response rates of $76 \%$ end-users and $67.5 \%$ managers respectively. This is followed by discussion and interpretation of findings, and development of a holistic framework for effective strategic change management in the Nigerian MCOTI, in response to the key research questions and hypotheses (RQ1 - RQ4; H1, H2, H3). In summary, Hypothesis H1 and H3 are rejected, however, the test results for Hypothesis $\mathrm{H} 2$ are inconclusive.

\section{End-user regression analysis}

From the results of the regression analysis, the null hypothesis $\mathrm{H} 1$ is rejected because an increase in the threat of substitutes, increase in industry investment, progressive legislation, increase in vertical integration, and increase in foreign direct investment, are drivers for strategic change in the MCOTI. However, an increase in technological innovation and global competitiveness support hypothesis $\mathrm{H} 1$. 


\section{Managers' regression analysis}

Hypothesis $\mathrm{H} 2$ is rejected because the results are inconclusive i.e. although there is an apparent positive relationship between managers' desire for 'gradual change', the results are not significant. Similarly, hypothesis $\mathrm{H} 3$ is rejected because managers in this study do think that a radical change is needed in the MCOTI in Nigeria.

\subsection{Thematic results from the semi-structured interviews involving top managers}

The manual and NVivo content analysis of the 13 semi-structured interviews, involving 13 top managers from five top companies in the MCOTI in Nigeria, was presented thematically, based on cluster analysis, which gives a hierarchical relationship between the codes/words used by participants. The results reveal participants' views on the internal factors influencing their preferences for either radical or gradual change in the Nigerian MCOTI. The interviews therefore provide in-depth understanding of how the change drivers and inhibitors in the MCOTI influence a firm's preference for radical or gradual approaches to strategic change management.

\subsection{The proposed holistic strategic change management framework for sustaining competitiveness in the Nigerian MCOTI}

The combination of both the quantitative and qualitative findings led to the development of the holistic framework in Figure 3.2. It has two key building blocks as its foundation: internal factors influencing the type of strategic change management approaches adopted and macroenvironmental and industry factors. The framework assumes that a radical or gradual approach to strategic change management should enable a firm to achieve strategic fit between its internal environment and external environment. This should reflect top managers' long-term orientation, level of uncertainty, and holistic decision making, in response to changes in both macro- 
environmental and industry factors. This framework has implications for the planning, implementation and control of radical or gradual strategic change management by firms in the Nigerian MCOTI.

In order to achieve the overarching aim of this research paper, a pragmatist-interpretivist research design was adopted, making use of a mix of quantitative data from explorative questionnaire surveys (to test three hypotheses, $\mathrm{H} 1, \mathrm{H} 2$ and $\mathrm{H} 3$ ); and qualitative data from evaluative semi-structured interviews. The questionnaire surveyed 135 top managers and 760 end-users within the Nigerian MCOTI, while 13 top managers took part in the semi-structured interviews. These surveys were carried out between 2011 and 2016. The data collected from both the questionnaires and interviews were subjected to statistical analysis and content analysis using SPSS and NVivo software respectively.

\subsection{Conclusions and Policy Recommendations}

This study has investigated the impact of strategic change management in the Nigerian Maritime Crude Oil Transportation Industry (MCOTI), with the overarching aim of providing a better understanding of strategic change management concepts, and how they can be effectively applied within the Nigerian MCOTI. Based on this background, and for Nigeria to achieve the United Nations Sustainable Development Goals (UN SDGs), especially on poverty and vulnerability reduction, decent work, enhanced trade and sustained economic growth will boost its economic competitiveness as targeted in the Economic Recovery and Growth Plan (ERGP) 2017 - 2020. Thus, the maritime sector must be provided with the critical infrastructure towards 
enhancing the transportation of commodities from the ports to the hinterland ${ }^{5}$. Further, optimizing maritime and energy sectors will serve as effective vehicles for job opportunities, poverty eradication and economic expansion. Being the catalyst for trade expansion and economic transformation, some of the impact pathways through which the maritime industry plays a critical role towards the realization of the UN SDGs in Nigeria include inter alia: promote indigenous commercial shipping capacity, enhance safety, security, maritime labour harmony as well as mitigate marine pollution.

Due to the steady economic expansion, supportive pro-investment environment, relative political stability and robust demand profile for maritime crude oil transportation infrastructure in Africa, the industry will stay on a strong trajectory into the future. According to International Maritime Bureau (IMB) statistics, reported incidents of pirate attacks in the Gulf of Guinea are declining, thereby driving regional trade in the region, 90 percent of which is conducted by sea (West Africa, 2015). However, two sub-regions within the African continent - the Horn of Africa and the Gulf of Guinea - portend the greatest incidence of maritime piracy and are characterised by low quality of institutions underlying their political economies (Hastings \& Phillips, 2015). Further, deficient of the Nigerian maritime capacities imply limited continental and regional strategy implementation. In response to these capacity challenges, China is making its impact on the continent with its infrastructure investment in Africa's entire maritime infrastructure, along with negotiating favourable trade accords resulting in a subsequent steep rise in trade between China and the African continent (UNCTAD, 2018). Further, it is expected that establishing the African Continental Free Trade Area will generate additional trade flows that will benefit the

\footnotetext{
${ }^{5}$ Every port must have a compliment of rail infrastructure and the plan outlines that by the end of 2021 Nigeria will have a standard gauge railway across the main North-South rail route, as 25 major highways and 44 roads are under construction across the six geo-political zones of the country.
} 
maritime transport industry on the continent (Brookings Institution, 2018). Based on this background, this paper concludes that, the quantitative and qualitative results/findings reveal that strategic change management impacts on the maritime crude oil transportation industry in Nigeria in a number if key areas. One of these policy outcomes is towards improving the living conditions of Nigerians, and providing the means of reducing extreme poverty, as well as strengthening the social platforms necessary for them to enjoy the benefits of shared prosperity, thereby contributing to mitigating severe poverty situation in the country. Other pertinent recommendations are follows:

- How to plan the change: It has been well argued in the literature that the global business environment is not static; therefore, this creates an avenue for organisations to always devise an action plan (strategic plan) that helps manage the unpredictable global business environment (Markiewicz, 2011; Hill et al., 2015). The findings in this research indicate the possible factors and motives influencing the adoption of either a gradual or radical approach to strategic change management, as part of a plan for managing organisational change within the Nigerian MCOTI. This concluded that, the Nigerian MCOTI, that has gone through different stages of industry transformation, this research has showcased the importance and necessity for the Nigerian maritime industry to understand the degree of impact and immediacy of internal environmental factors, e.g. long-term orientation, organic adaptation, level of uncertainty regarding the effectiveness of the Cabotage Act (see Figure 3.2); and external environmental factors e.g. effective government policies; efficient politico-legal forces; technological innovation, that enhance the right action plan to bring about effective management of change within the Nigerian MCOTI. 
How to implement change: The literature review reveals that strategic change within the global business environment is inevitable; however, it has been observed that one of the greatest challenges of change implementation is communication (Brinkschroder, 2014). An organisation might have the best change policy or plans but the manner in which the change process is communicated will determine the effectiveness of or resistance to the change. This indicates that for gradual and radical change to be effectively implemented, the people involved need to understand the necessity for the change and how the change will impact on them. In the context of the Nigerian MCOTI, change implementation has been one of the greatest challenges facing the industry.

How to monitor and control change: In attempting to understand the monitoring and control (integral part) of change within an organisation or industry, there is a clear indication that every stakeholder within the organisation or industry must have a good grasp of the implemented change. The importance of this stage of the change process is to determine the extent to which the change is being communicated and embraced by the stakeholders. This helps to determine whether everybody involved in change processes is travelling in the same direction. The monitoring and control of change practices within the Nigerian MCOTI has been weak because of the inefficiency in the communication of governmental and maritime policies to all stakeholders within the Nigerian MCOTI. Addressing the specific needs of the vulnerable groups will require increasing and improving the access of the vulnerable stakeholders to productive assets and decision-making processes. 
One of the major limitations of the study relate to the fact that it was difficult to involve a much wider range of participants because of the political unrest in some parts of Nigeria during the fieldwork. In order to further this research in Nigeria and the entire African continent, it will be important to access the United Nations Cooperation on Trade and Development (UNCTAD) technical assistance on 'Building capacities of developing countries to shift towards sustainable freight transport', which aims to strengthen the capacities of policymakers, transport operators and key financial institutions in Africa, thereby fostering sound transport policy measures and adequate financing actions and mechanisms. Consequently, this will deliver essential services to the most vulnerable segments of the Nigerian population and bear positive externalities on the overall population, thereby strengthening the capacities and empowering the most vulnerable segments of the population and justifying the rationale for UNCTAD technical assistance.

\section{References}

Aderamo, A. J. (2012). Road Traffic Accident Injuries and Productivity in Nigeria. Journal of Asian Scientific Research, 2(7), pp. 334-344.

Akinbami, J. F. K. and Fadare, S. O. (1997). Strategies for Sustainable Urban and Transport Development in Nigeria. Transport Policy, 4(4), pp. 237-245.

Aluko, A. (2013). Cabotage Act: Issues and Policy Recommendations. [online] Punch. Available at: $\quad$ http://www.punchng.com/opinion/cabotage-act-issues-and-policy-recommendations/ [Accessed 30/05/2013].

Aroh, K. N., Ubong, L. U., Eze, I. M., Harry, J. C., Umo-Otong and Gobo, A. E. (2010). Oil Spill Incidents and Pipeline Vandalization in Nigeria Impact on Public Health and Negation to Attainment of Millennium Development Goal: the Ishiagu Example. Disaster Prevention and Management, 19(1), pp. 70-87.

Babatunde, B. O. and Adebisi, A. O. (2012). Strategic Environmental Scanning and Organisation Performance in a Competitive Business Environment, Economic Insights - Trends and Challenges. Available at: http://upg-bulletin-se.ro/archive/2012-1/3.\%20Babatunde_Adebisi.pdf [Accessed 31/01/2018]. 
Batras, D., Cameron, D. and Smith, B. J. (2014). Organizational Change Theory: Implications for Health Promotion Practice. Health Promotion International, pp. 1-11.

Barney, J. B. and Hesterly, W. S. (2012). Strategic Management and Competitive Advantage Concepts.

Available

at:

http://teaching.up.edu/BUS580/bps/Barney $\% 20$ and $\% 20 H e s t e r l y, \% 202008, \% 20 \mathrm{ch} 3$ VRIO $\% 20 \mathrm{in}$ ternal\%20analysis.pdf [Accessed 26/01/2018].

Bello-Olowookere, G. B. (2011). The Effects of Cabotage Regime on Indigenous Shipping in Nigeria. Available at: https://commons.wmu.se/cgi/viewcontent.cgi?referer=https:/www.google.co.uk/\&httpsredir=1\& article $=1175 \&$ context $=$ all_dissertations [Accessed 26/02/2017].

Benetrix, A. S., Lane, P. R. and Shambaugh, J. C. (2014). International Currency Exposures, Valuation Effects and the Global Financial Crisis. Journal of International Economics, pp. 1-48.

Bormann, K. C. and Rowold, J. (2016). Transformational Leadership and Followers' Objective Performance over Time: Insight from German Basketball. Journal of Applied Sport Psychology, 28(3), pp. 367-373.

Brinkschroder, N. (2014). Strategy Implementation: Key Factors, Challenges and Solutions. 4th IBA Bachelor Thesis Conference, 1-9.

Brookings Institution. (2018). Strengthening Regional Value Chain: What's the role of the African Continental Free Trade Agreement? Africa in Focus. 21 st March.

Butcher, T., Dickens, R. and Manning, A. (2012). Minimum Wages and Wage Inequality: Some Theory and an Application to the UK. CEP Discussion Papers, CEPDP1177. London, UK: Centre for Economic Performance, London School of Economics and Political Science.

Chen, I. C., Hill, J. K., Ohlemuller, R., Roy, D. B. and Thomas, C. D. (2011). Rapid Range Shift of Species Associated with High Levels of Climate Warming. Science, 333, pp.1024-1026.

Cornelissen, J. (2017). Corporate Communication, Theory and Practice. London: Sage Publications.

Creswell, J. W. (2013). Steps in Conducting a Scholarly Mixed Methods Study. [online] DigitalCommons@University of Nebraska - Lincoln. Available at: http://digitalcommons.unl.edu/cgi/viewcontent.cgi?article $=1047 \&$ context $=$ dberspeakers [Accessed 14/12/2015].

Damachi, B. B and Zhaosheng, Y. (2005). "The Nigeria Shipping Indigenous Companies". Maritime Policy \& Management, 32(1), pp 31-38. 
Dibb, S. and Simkin, L. (2010). Judging the Quality of Customer Segments: Segmentation Effectiveness. [online] Open Research Online. Available at: http://oro.open.ac.uk/22398/2/JSM_final.pdf [Accessed 31/01/2018].

Egberonge, F. O. A., Nwilo, P. C. and Badejo, T. (2006). Oil Spill Disaster Monitoring along Nigerian Coastline, Marine and Coastal Zone Management, Environmental Planning Issues, Promoting Land Administration and Good Governance, 5th FIG Regional Conference. Available at: http://www.fig.net/pub/accra/papers/ts16/ts16 06 egberongbe etal.pdf. [Accessed 02/10/2017].

Ememe, J. (2017). Leadership Strategies for Managing Change in the Nigerian Banking Industry. USA: Walden Dissertation and Doctoral Studies Collection. Available at: https://scholarworks.waldenu.edu/cgi/viewcontent.cgi?referer=https:/www.google.co.uk/\&httpsr edir $=1 \&$ article $=5981 \&$ context $=$ dissertations $[$ Accessed 21 Feb. 2019].

Emenyonu, H. K., Onyema, K. O., Ahmodu, K. O. and Onyemechi, C. (2016). Econometric Analysis of Seaport Development and Its Impact on the Economic Growth of Nigeria. International Journal of Advanced Research, 4(2), pp. 133-138.

Etekpe, A. (2007). The Politics and Conflicts over Oil and Gas in the Niger Delta Region: the Bayelsa State Experience 1990-2006. Port Harcourt: TowerGate Resources.

Fashoyin, T. (2008). Policy Reforms and Employment Relations in Zambia, International Labour Organisation, No. 29. [online] ILO. Available at: http://www.ilo.org/wcmsp5/groups/public/--africa/---ro-addis_ababa/---sro-harare/documents/publication/wcms_228802.pdf. Accessed 10/09/2014]

Firuzjaeyan, A. A., Firuzjaeyan, M. and Sadeghi, B. (2015). A Survey of the effect of Organisational Culture on Organisational Commitment Based on Allen and Meyer Model (Case Study: High School Teachers of Bandpey Region). International Journal of Academic research of Academic Research in Business and Social Sciences, 5(1), pp. 1-9.

Gould, A. M. and Desjardins, G. (2015) A Spring-clean of Michael Porter's Attic, The Canadian Telecommunications Sector as an Exemplar of Refurbished Generic Strategy. Competitiveness Review, 25(3), pp. 310-323.

Harinarain, N. et al. (2013). Organisational Culture of the South African Construction Industry. Available at: file:///C:/Users/Akinseye/Downloads/94080-241377-1-PB.pdf Accessed $15 / 12 / 2017]$.

Hastings, J. and Phillips, S. (2015). Maritime piracy business networks and institutions in Africa. African Affairs, 114(457), pp. 555-576.

Heidhues, F. and Obare, G. (2011). Lessons from Structural Adjustment Programmes and their Effects in Africa. Quarterly Journal of International Agriculture, 50(1), pp. 55-64. 
Ifeanyi, M. E., Osseo-Asare, A. E. and Origho, O. (2015). Manufacturing Industry Competitiveness: The Impact of Socio-Culture Factors on FDI inflows to Nigeria Since 2000. Available http://sure.sunderland.ac.uk/5885/1/FDI, \%20Firm\%20Competitiveness, \%20Nigeria_AIB \%20US \%20Conference 12October2015.pdf. [Accessed 21/01/2018].

Johnson, G., Scholes, K. and Whittington, R. (2008). Exploring Corporate Strategy. $8^{\text {th }}$ ed. England: Prentice Halt.

Joseph-Raji, Gloria Aitalohi; Timmis, Emilija. 2018. Nigeria biannual economic update : connecting to compete (English). Washington, D.C. : World Bank Group. http://documents.worldbank.org/curated/en/769551524576691390/Nigeria-biannualeconomic-update-connecting-to-compete. [Accessed 21/02/2019].

Kandt, R. K. (2002). Organisational Change Management Principle and Practices. Available at: http://trs-new.jpl.nasa.gov/dspace/bitstream/2014/10570/1/02-2625.pdf [Accessed 09/01/2018].

Inyang, B. J., Enuoh, R. O. and Ekpenyong, O. E. (2014). The Banking Sector Reforms in Nigeria: Issues and Challenges for Labour-Management Relations. Journal of Business Administration Research, 3(1), pp. 82-90.

Kotler, P. and Keller, K. L. (2012). Marketing Management. New Jersey: Prentice Hall.

Lin, Y. T. et al. (2012). Vertical Integration under Competition: Forward, Backward, or No Integration? Forthcoming in Production and Operations Management. Available at: http://public.kenan-flagler.unc.edu/faculty/parlakturk/papers/P9-Vertical\%20Integration-POMSF.pdf [Accessed 31/01/2018].

Luqman, S. and Lawal, F. M. (2011). The Political Economy of Oil and the Reform Process in Nigeria's Fourth Republic Successes. International Refereed Research Journal, 2(2), pp. 59-76.

Ndoms, E. (2005). Logistics and Transportation in Oil and Gas Exploration in Nigeria. Available at: http://www.touchbriefings.com/pdf/1736/Echo_Ventures tech.pdf [Accessed 02/10/2012].

Lindenau, M. and Bohler-Baedeker, S. (2014). Citizen and Stakeholder Involvement: A Precondition for Sustainable Urban Mobility. Transportation Research Procedia, 4, pp. 347-360.

Makinde, T. (2005). Problems of Policy Implementation in Developing Nations:

The Nigerian Experience. Journal of Social Science, 11(1), pp. 63-69.

Mantere, S. (2012). Reversal of Strategic Change. Academy of Management Journal, 55(1), pp. 172-196.

Matthewman, J. (2013). How Organisation culture Impact on Business Performance, Towers Watson. Available at: http://www.ilcbh.org/ilc2013/images/presentations/Jim\%20Matthewman\%20- 
\%20How\%20organisation\%20culture\%20impacts\%20business\%20performance.pdf [Accessed $15 / 12 / 2014]$

Mullai, A. (2006). Maritime Transport and Risks of Packaged Dangerous Goods. Available at: file:///C:/Users/Mi-

PC/Downloads/Maritime_Transport_and_Risks_of_Packaged_Dangerous_Goods.pdf [Accessed 28/01/2018].

Narula, K. (2019). Maritime Security and its Role in Sustainable Energy Security. In Maritime Dimension of Sustainable Energy Security. Lecture Notes in Energy, 68. Singapore: Springer.

Ndikom, B. C. (2013). A Critical Evaluation of the Challenges and Opportunities of Shipping Line Service in Nigeria. Greener Journal of Business and Management Studies, 3(5), pp. 241250.

Odularu, G. and Aluko, A. O. (2014). Enhancing the Policy and Legislative Space for Strengthened Regional Agricultural Innovation in Africa. Journal of African Economics Fellows Alumni Network, 14(2), pp. 4-5. Available at: http://www.csae.ox.ac.uk/scholarships/JAE/newsletters/2.\%20JNL\%20Vol.1\%20Issue\%202.pdf [Accessed 22/07/2016].

Nigeria Logistics Risk Report - Q1 2019. (2019). BMI Risk Reports, 1.

Nigeria Trade and Investment Report - Q1-2019. (2019). BMI Risk Reports, 1.

Nwinyokpugi, P. (2018). Organisational Change Management and Employees Productivity in the Nigeria Banking Sector. IOSR Journal of Business and Management (IOSR-JBM), [online] 20(1 - Ver. VIII), pp.11 - 20. Available at: http://www.iosrjournals.org/iosr-jbm/papers/Vol20issue1/Version-8/B2001081120.pdf [Accessed 21 Feb. 2019].

Odularu, G. O. (2008). Crude Oil and the Nigerian Economic Performance. Available at: http://www.ogbus.ru/eng/authors/Odularo/Odularo_1.pdf Accessed 22/01/2018].

Oehmichen, J., Schrapps, S. and Wolff, M. (2016). Who Needs Experts Most? Board Industrial Expertise and Strategic Change - A Contingency Perspective. Strategic Management Journal.

Ogunniyi, M. B. and Igberi, C. O. (2014). The Impact of Foreign Direct Investment on Poverty Reduction in Nigeria. Journal of Economics and Sustainable Development, 5(14).

Ogwu, F. A. (2011). Challenges of Oil and Gas Pipeline Network and the Role of Physical Planners in Nigeria. FORUM Ejournal, 10, pp. 41-51.

Olarewaju, A. A. and Folarin, E. A. (2012). Impact of External Business Environment on Organisational Performance in the Food and Beverage Industry in Nigeria. British Journal of Arts and Social Sciences, 6(2), pp. 194-201. 
Omotosho, J. A. et al. (2009). Problems and Counselling Needs of Unemployed Youths in Nigeria. The Open Area Studies Journal, 2, pp. 1-6.

Origho, O., Osseo-Asare, A. E., Bhate, S. and Ifeanyi, M. E. (2015). Service Quality Capacity Impacting Firms' Competitiveness in the Nigerian Financial Industry - From Customers' Perspective. Available at: http://sure.sunderland.ac.uk/5887/1/Firm\%20Competitiveness\%2C\%20Financial $\% 20$ Services $\% 2$ 0Quality $\% 2$ C $\% 20$ Nigeria_AIB $\% 20$ US\%20Conference_05\%200ctober\%202015.pdf [Accessed $31 / 01 / 2018]$.

Prandeka, M. and Zackos, V. (2014). The Greek Maritime Transport Industry and its Influence on the Greek Economy. [online] Eurobank Research. Available at: https://www.eurobank.gr/Uploads/Reports/ECONOMYMARKETS_wpMAY2014.pdf [Accessed Date 14/07/2016].

Porter, E. M. (2008). The Five Competitive Forces that Shape Strategy. Harvard Business Review.

Saunders, M. et al. (2012). Research Methods for Business Students. $6^{\text {th }}$ ed. England: Pearson Education.

Slater, S. F. and Olson, E. M. (2002). A Fresh Look at Industry and Market Analysis. Business Horizons, 45(1), pp. 15-22.

Teece, D. J., Pisano, G. and Shuen, A. (1997). Dynamic Capabilities and Strategic Management. Strategic Management Journal, 18(7), pp. 509-533.

Trigeorgis, L. and Reuer, J. J. (2016). Real Options Theory in Strategic Management. Journal of Strategic Management, 38(1), pp. 42-63.

UNCTAD. (2018). Challenges faced by Developing Countries in Competition and Regulation in the Maritime Transport Sector. Intergovernmental Group of Experts on Competition Law and Policy Seventeenth Session. 11 - 13 July, 2018.

UNCTAD. (2018). Sustainable Freight Transport in Support of the 2030 Agenda for Sustainable Development. Multi-year Expert Meeting on Transport, Trade Logistics and Trade Facilitation. Geneva, 21 - 23 November, 2018.

Vrey, F. (2012). Maritime Aspects of Illegal Oil-bunkering in the Niger Delta. Australian Journal of Maritime and Ocean Affairs, 4(4), pp. $109-115$.

Waring, T. and Wainwright, D. (2008). Issues and Challenges in the Use of Template Analysis: Two Comparative Case Studies from the Field. The Electronic Journal of Business Research Methods, 6(1), pp. 85-94. 
West Africa: Anti-piracy push faces multiple obstacles. (2015). OxResearch Daily Brief Service, p. n/a.

World Bank. (2017). Nigeria Bi-Annual Economic Update: Fragile Recovery. Available at: http://documents.worldbank.org/curated/en/349511494584937819/pdf/114996-WP-P163291PUBLIC-NEUNoFinalfromPublisher.pdf [Accessed 26/01/2017].

World Bank. 2019. Nigeria : A Short Update on Poverty and Shared Prosperity (English). Nigeria Poverty Briefing Note. Washington, D.C. : World Bank Group. http://documents.worldbank.org/curated/en/636531549879664295/Nigeria-A-ShortUpdate-on-Poverty-and-Shared-Prosperity. [Accessed 21/02/2019].

Young, J. (2012). A Fresh Start: Fixing the Transportation Sector in Nigeria, Frontier Market Intelligence. Available at: http://www.tradeinvestnigeria.com/feature_articles/1210047.htm [Accessed 21/09/2017].

Zuccaro, S. J. (2007). Trait-Based Perspectives of Leadership. American Psychological Association, 62(1), pp. 6-16. 